\title{
Yield stability of dry bean genotypes in Honduras'
}

\author{
David W. Unander," R. Día-Donaire, James S. Beaver, ${ }^{4}$ \\ Jonathan Cerna-García and Dinnie Rueda ${ }^{5}$
}

\begin{abstract}
Bean (Phaseolus vulgaris L.) cultivars are grown under diverse environmental conditions in Central America because of geography, multiple growing seasons and variable inputs. The regression of mean genotype yields onto mean environment yields may provide useful information for selecting beans with greater yield stability when grown under these conditions. The principal objective of this research was to test yield stability of bean cultivars and promising breeding lines across a range of environments representative of the bean growing regions of Honduras. In 1984, 25 cultivars/breeding lines of various origins were grown in $\mathbf{2 3}$ field trials in Honduras. The trials were conducted during two seasons and in three different departments. Stability was examined on the basis of mean square deviations (MSD) from regression. Large rank order changes among mean seed yield of genotypes were evident when different seasons and departments were compared. A highly significant correlation of the regression slope (b) with mean genotype yield supported use of MSD to assess yield stability. Mean yield and MSD were not correlated. The two determinate cultivars in the trial had poor stability characteristics. Honduran varieties had greater yield and betfer stability characteristics than most entries in the trial. Black-seeded lines 'B-190', '3B-5-1' and ' $8325-7$ ' had high mean yield and good stability characteristics. These results show the importance of testing for yield stability if a cultivar is to be released for use in different regions and seasons in Central American countries. Also high yield and stability, judged on the basis of MSD, can occur in the same genotype.
\end{abstract}

'Manuscript submitted to Editorial Board 25 April 1989. Joint contribution of Puerto Rico Agric. Exp. Stn., Mayagüez, P. R. 00708 and the Escuela Agrícola Panamericana, El Zamorano, Honduras. This research was supported in part by Title XII Bean/Cowpea CRSP of the U.S. Agency for International Development under Grant No. AID/DSAN/ XII-G-0261. Received April, 1989.

${ }^{2}$ Former Assistant Professor, currently Research Associate for medicinal plants, Div. of Population Oncology, Fox Chase Cancer Center, 7701 Burholme Ave., Philadelphia, PA 19111.

${ }^{3}$ Former Associate Professor, Escuela Agricola Panamericana, El Zamorano, Honduras.

${ }^{4}$ Associate Professor, Dept. of Agronomy and Soils.

- Former Graduate Student.

${ }^{6}$ Field Research Assistant. 


\section{RESUMEN}

Estabilidad del rendimiento de algunos genotipos de habichuela en Honduras

Varias cultivares de habichuela (Phaseolus vuigaris L.) se sembraron en América Central en una variedad de condiciones ambientales debido a la geografía de las áreas de siembra y a las diversas estaciones de crecimiento a lo largo de todo el año. Las regresiones de los promedios de rendimiento de los genotipos y de los rendimientos medios por ambiente pueden proveer información valiosa para seleccionar líneas con una mejor estabilidad de rendimiento. El objetivo principal de esta investigación fue estudiar la estabilidad de rendimiento de cultivares y líneas de mejoramiento de habichuela con características prometedoras para autorizar su uso en tres áreas productoras de habichuela de Honduras. Los experimentos se sembraron duranie dos épocas de siembra en tres departamentos del país. La estabilidad de rendimiento se determinó a partir de las desviaciones del cuadrado medio (MSD). De las regresiones se pudo observar grandes cambios en el orden de los genotipos cuando se compararon las épocas y los lugares de siembra. Una correlación altamente significativa entre la pendiente de regresión y el promedio de rendimiento por genotipo respalda el uso del método de las MSD para estudiar estabilidad de rendimiento. El promedio de rendimiento y las MSD no esfuvieron correlacionados. Las dos cultivares determinadas incluidas en los exprerimentos presentaron características pobres de estabilidad. De las cuatro variedades de Honduras, dos de ellas tuvieron mejores rendimientos y estabilidad que la mayoría de las cultivares incluidas en los experimentos. Las lineas negras B-190, 3B-5-1 y 8325-7 presentaron buena estabilidad y excelentes promedios de rendimiento. Estos resultados muestran la importancia que tiene estudiar la estabilidad de rendimiento de una cultivar de frijol que se autoriza para sembrarse en diferentes regiones y estaciones de siembra de los países centroamericanos y también nos indica que y los altos rendimientos y la estabilidad medidos a base de las MSD pueden estar presentes en el mismo genotipo.

\section{INTRODUCTION}

Dry beans (Phaseolus vulgaris L.) have been a staple food in Central America since pre-Colombian times. In this region, yield stability is an important trait to consider in plant breeding. This is due not only to the geography, which presents a wide variety of elevations and rainfall patterns within relatively short distances, but also to the multiple growing seasons possible in tropical latitudes and the divergent incomes; and hence, farming inputs of growers. Hildebrand (8) recommended use of on-farm trials to obtain information about cultivar stability, and demonstrated the utility of this approach in Malawi, East Africa. This approach permits financial resources to go further in testing cultivars, and also provides data on stability relative to various types of management by different farmers.

Becker (4) noted that the different techniques for measuring yield stability are related and fall under two basic concepts, which he called the biological concept and the agronomic concept. The biological concept, or homeostatis, measures the degree to which yield is unchanging with environment. The agronomic concept measures interactions with the en- 
vironment. Eberhart and Russell (6) defined stability as an average yield response of genotypes to environments of varying productivity and minimum deviations from regression of genotype yield onto environmental yield. According to Becker (4) the regression slope is a measure of homeostatis, and the mean square of the deviations (MSD) from the regression is a measure of agronomic stability among differing environments. Rosielle and Hamblin (11) showed that unless genetic variance in stress environments is greater than genetic variance in non-stress or optimum environments, regression slope must be correlated with mean yield. Allen et al. (1) found that genetic variances of barley (Hordeum vulgare L.), wheat (Triticum aestivum L.) oats (Avena sativa L.), soybean [Glycine max (l.) Merr.] and flax (Linum usitatissimum L.) were lower in stress environments than in intermediate or favorable environments on the basis of many yield trials with up to 41 entries over multiple locations and years. Rosielle and Hamblin (11) cite other references to show that genetic variance from unfavorable environments is commonly less than that from favorable environments. Given the strong relationship between mean yield and regression slope, a measure of agronomic stability such as MSD seems more appropriate for selecting stable genotypes.

The objective of this experiment was to test local cultivars and advanced breeding lines for yield stability across a typical range of growing conditions in the principal bean-growing regions of Honduras.

\section{MATERIALS AND METHODS}

Twenty-five dry bean cultivars and breeding lines were grown in 27 replicated yield trials in Honduras in 1984. The majority were in on-farm locations. Ten of the tests were in pairs in five environments comparing yield with and without fungicide. For the yield stability analysis the different fungicide treatments were considered as distinct environments. Table 1 lists genotypes used in the experiment, and their origin, seed color and growth habit. There was a 10- to 15-day range in maturity between the earliest and the latest cultivars. Four local cultivars and landraces ('Desarrural', 'Cuarenteño', 'Zamorano' and 'Danli 46') were included as checks. Each test was a randomized complete block with three replicates. Experimental units consisted of two 4-m rows planted $0.5 \mathrm{~m}$ apart at $200,000 \mathrm{seed} / \mathrm{ha}$. Tests were planted in seasons considered suitable for bean cultivation, with respective harvests in September and December, and in the bean growing regions of the departments of Olancho, El Paraíso and Francisco Morazán. Bean plantings coincided with generally favorable rainfall patterns. Seed yield was determined by harvesting all plants in each experimental unit at maturity. Data from trials which showed no significant differences for seed yield among cultivars in the analysis of variance were not included in the yield stability analysis. 
TABLE 1.-Seed color, growth habit, origin, mean seed yield, overall rank of seed yield and deviation mean square of 25 bean genotypes planted in replicated yield

trials in Honduras in 1984

\begin{tabular}{lccccccc}
\hline Genotype & Code & $\begin{array}{c}\text { Seed } \\
\text { color }\end{array}$ & $\begin{array}{c}\text { Growth' } \\
\text { habit }\end{array}$ & Origin & $\begin{array}{c}\text { Mean } \\
\text { seed } \\
\text { yield }\end{array}$ & $\begin{array}{r}\text { Overall } \\
\text { rank of } \\
\text { seed yield }\end{array}$ & $\begin{array}{c}\text { Deviation } \\
\text { mean } \\
\text { mean square }\end{array}$ \\
B-190 & & & & & kg/ha & & \\
L-226 & A & black & 2 & PR & 1308 & 5 & \\
3M-81 & C & white & 2 & MI & 1013 & 22 & \\
2W-33-2 & D & white & 2 & PR & 1009 & 23 & \\
3M-150 & E & red & 1 & PR & 1059 & 18 & \\
3B-5-1 & F & black & 2 & PR & 1167 & 12 & $>$ \\
L227 & G & white & 2 & MI & 1250 & 7 & $<$ \\
3M-152 & H & red & 1 & PR & 12067 & 17 & \\
3B-38 & I & black & 2 & PR & 1346 & 10 & $>$ \\
La Vega & J & black & 2 & PR & 1308 & 2 & \\
8325-58B & K & black & 2 & PR & 753 & 25 & \\
8325-7 & L & black & 2 & PR & 1339 & 3 & \\
N80045 & M & white & 2 & MI & 1204 & 9 & \\
N80080 & N & white & 2 & MI & 1040 & 19 & $<$ \\
N80061 & O & white & 2 & MI & 1150 & 14 & \\
8241-127 & P & white & 2 & PR & 1025 & 21 & \\
Desarrural & Q & red & 2 & HN & 1242 & 8 & \\
Cuarenteño & R & red & 2 & HN & 1125 & 15 & $<$ \\
Zamorano & S & red & 2 & HN & 936 & 24 & $>$ \\
Danli 46 & T & red & 2 & HN & 1352 & 1 & \\
BAT 1654 & U & red & 2 & CT & 1110 & 16 & \\
RAB 205 & V & red & 2 & CT & 1171 & 11 & \\
BAT 1217 & W & red & 2 & CT & 1276 & 6 & \\
Huetar & X & red & 2 & CT & 1157 & 13 & \\
RAB 201 & Y & red & 2 & CT & 1037 & 20 & $<$ \\
\hline
\end{tabular}

$11=$ determinate and $2=$ indeterminate.

${ }^{2} \mathrm{PR}=$ Puerto Rico, $\mathrm{MI}=$ Michigan, $\mathrm{HN}=$ Honduras, and $\mathrm{CT}=$ CIAT .

$3>=$ significantly greater and $<=$ significantly less than the pooled deviation mean square at $P=0.05$.

A phenotypic model derived from Freeman (7) for bean yield $Y_{i j k}$ of the $i^{\text {th }}$ genotypic entry in the $k^{\text {th }}$ replicate of the $j^{\text {th }}$ environment may be expressed as:

where, $\quad m$ is the overall mean seed yield,

$$
Y_{i j k}=m+d_{i}+E_{j}+B_{i}\left(E_{j}\right)+g_{i j}+e_{i j k}
$$

$d_{i}$ is the effect of the $i^{\text {th }}$ genotype, $E_{j}$ is the effect of the $j^{\text {th }}$ environment, (equal to $Y$.j. for the $j$ environment in the regression analysis), $b_{i}\left(E_{j}\right)$ is the linear regression coefficient from the regression of $Y_{i j}$ on $E_{j}$ for the $i^{\text {th }}$ genotype, $\mathrm{g}_{i j}$ is the deviation from regression and $\mathrm{e}_{\mathrm{ijk}}$ is the random error. 
Although $b_{i}$ was calculated, stability was examined on the basis of MSD, the mean square of the deviations from the regression. A pooled mean square of the deviations was calculated and used to test for significantly larger or smaller MSD values. This procedure was followed for an analysis of stability over all environments. Spearman rank correlations were calculated among genotype means by environmental subset, and among means, $b$-values and MSD values.

\section{RESULTS AND DISCUSSION}

Twenty-three trials showed significant differences in seed yield among cultivars. Thirteen of the trials had a September harvest, and 10 had a December harvest. Seven of the trials were from El Paraíso, 12 were from Olancho, and four from trials conducted at the Escuela Agrícola Panamericana at El Zamorano in the Department of Francisco Morazán. Olancho and El Paraíso account for about $40 \%$ of the total area in Honduras planted to beans and about $52 \%$ of the production (10).

Mean seed yields of genotypes over the 23 environments ranged from 752 to $1352 \mathrm{~kg} / \mathrm{ha}$ with an overall mean of $1146 \mathrm{~kg} / \mathrm{ha}$. Environmental means ranged from $559 \mathrm{~kg} / \mathrm{ha}$ (San Marco, El Paraíso, in the second season) to $1805 \mathrm{~kg} / \mathrm{ha}$ (El Plomo, Olancho, in the first season). Means of growing seasons were 1370 and $848 \mathrm{~kg} / \mathrm{ha}$ for the first and second seasons, respectively. Mean seed yields of regions were 1225, 923 and 1302 $\mathrm{kg} / \mathrm{ha}$ for Olancho, Paraíso and the Zamorano Valley, respectively. The lower yields during the second season were attributed to drought.

Yields of genotypes among environmental subsets were positively and significantly correlated (table 2). Means among seasons were positively and significantly correlated by Spearman rank correlations $(r=$ 0.41 ). The three possible Spearman correlations among means by department were significant and similar in magnitude ranging from $r=0.54$ to $r=0.61$. Some large rank order changes between seasons or departments were noted for certain genotypes, such as ' $3 \mathrm{M}-150$ ' (E), 'Desarrural' (Q) and 'Zamorano' (S) (table 2). Large rank order changes in genotypes among environmental subsets (table 2) could also be identified by high MSD values (fig. 2). It should be noted, however, that overall MSD values were not useful in identifying adaptation to specific environments. For example, Desarrural performed particularly well when planted in Olancho during the first growing season. The ranking of yields of environmental subsets permitted the identification of specific adaptation of certain genotypes.

All regressions of mean yields of genotypes onto mean environmental yields were highly significant, with $b_{i}$ ranging from 0.32 to 1.37 . The Spearman correlation of $b_{i}$ with mean yield of genotypes over all environments was positive and significant $(r=0.64)$. The positive relationship between $b_{i}$ and genotype mean yield illustrated in figure 2 supports the observations of Rosielle and Hamblin (11). 
TABLE 2.-Ranks of seed yield means from five subsets of environments of 25 bean. genotypes planted in replicated trials in Honduras in 1984

\begin{tabular}{|c|c|c|c|c|c|}
\hline \multirow[b]{3}{*}{ Genotype } & \multicolumn{5}{|c|}{ Environmental subset } \\
\hline & \multicolumn{2}{|c|}{ Growing season } & \multicolumn{3}{|c|}{ Department } \\
\hline & First & Second & Paraíso & Olancho & F. Morazán \\
\hline B-190 & 4 & 5 & 6 & 4 & 3 \\
\hline $\mathrm{L}-226$ & 23 & 14 & 17 & 23 & 19 \\
\hline $3 \mathrm{M}-81$ & 14 & 25 & 25 & 16 & 24 \\
\hline $2 W-33-2$ & 19 & 16 & 23 & 19 & 12 \\
\hline $3 M-150$ & 21 & 1 & 13 & 17 & 4 \\
\hline $3 B-5-1$ & 9 & 4 & 7 & 6 & 8 \\
\hline L227 & 17 & 23 & 21 & 15 & 22 \\
\hline $3 M-152$ & 13 & 6 & 4 & 12 & 10 \\
\hline $3 B-38$ & 5 & 2 & 2 & 7 & 1 \\
\hline La Vega & 3 & 8 & 5 & 3 & 7 \\
\hline $8325-58 \mathrm{~B}$ & 25 & 24 & 24 & 25 & 25 \\
\hline $8325-7$ & 7 & 3 & 1 & 8 & 2 \\
\hline$N-80045$ & 8 & 17 & 11 & 9 & 9 \\
\hline N-80080 & 22 & 12 & 22 & 18 & 18 \\
\hline$N-80061$ & 11 & 20 & 15 & 14 & 6 \\
\hline $8241-127$ & 20 & 22 & 20 & 22 & 13 \\
\hline Desarrural & 6 & 11 & 19 & 2 & 11 \\
\hline Cuarenteño & 15 & 18 & 10 & 13 & 23 \\
\hline Zamorano & 24 & 7 & 14 & 24 & 21 \\
\hline Danli 46 & 1 & 9 & 3 & 1 & 16 \\
\hline BAT 1654 & 16 & 19 & 8 & 20 & 14 \\
\hline RAB 205 & 10 & 13 & 9 & 11 & 17 \\
\hline BAT 1217 & 2 & 10 & 12 & 5 & 5 \\
\hline Huetar & 12 & 15 & 16 & 10 & 15 \\
\hline RAB 201 & 18 & 21 & 18 & 21 & 20 \\
\hline
\end{tabular}

Values for MSD and mean yield over all environments were not significantly correlated. Therefore, the simultaneous selection for greater yield and stability may be possible. A scatter dilagram of MSD and mean yields of genotypes can be divided into four quadrants using the grand mean for yield and the pooled MSD (fig. 2). Genotypes which fell in the lower right hand quadrant in figure 2 had greater than average mean yields and lower than average MSD.

The determinate genotypes ' $3 \mathrm{M}-152$ ' and ' $3 \mathrm{M}-150$ ' had deviation mean squares significantly greater than those of most genotypes in the trials. The poor yield stability of the determinate growth habit has been reported for beans in the Dominican Republic (2) and Michigan (9) and for soybeans in Illinois (3). In contrast, the indeterminate architectural genotypes, 'N80045', 'N80080', and 'N80061', had better than average stability. Therefore, it appears that the architectural traits of beans for Honduras could be modified without affecting yield stability. 


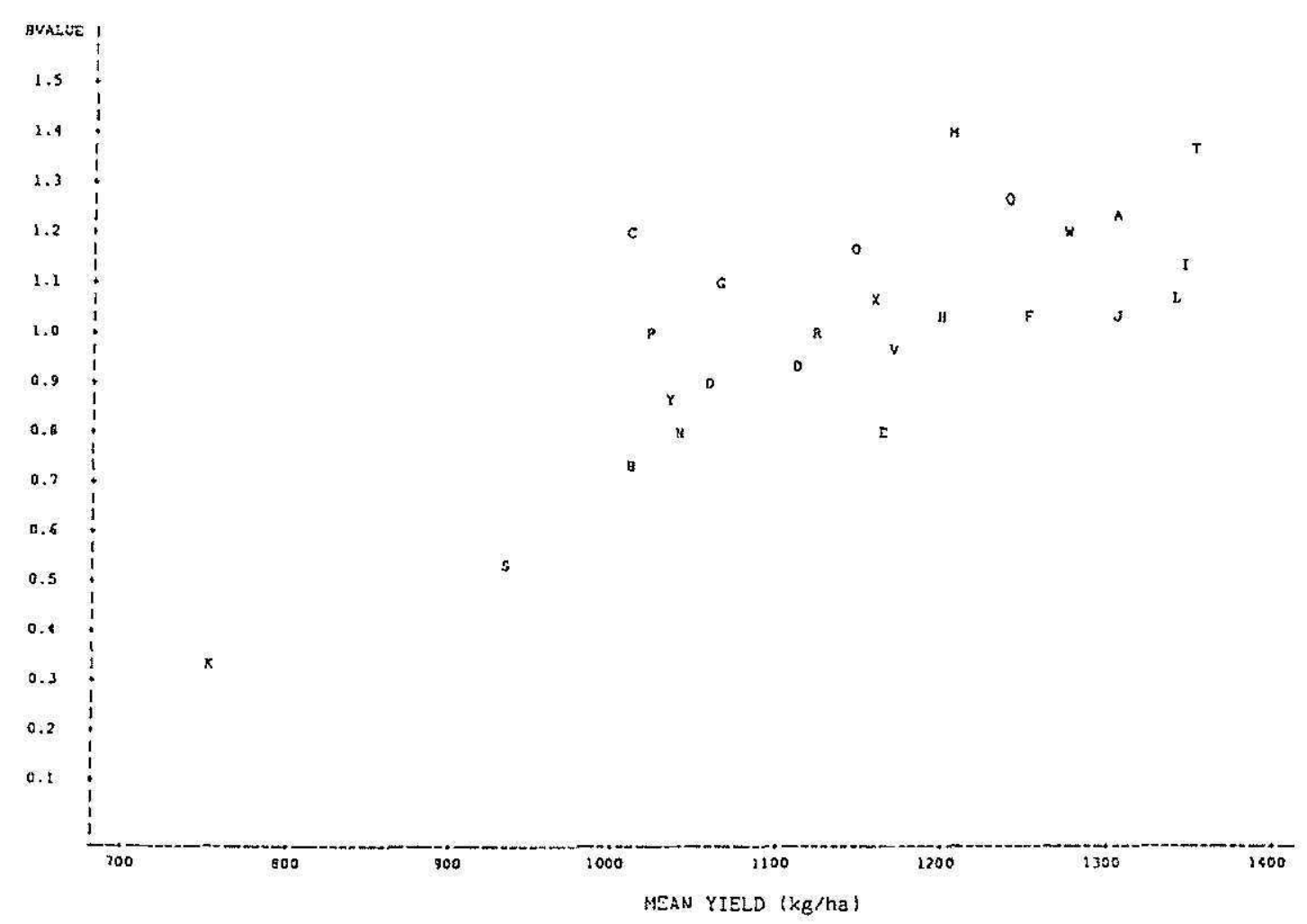

Frg. 1.-Scatter diagram of bean genotype means yields in $\mathrm{kg} / \mathrm{ha}$ and regression coefficients from the regression of mean yields of genotypes onto mean environmental yields. Genotypes are represented by letters using the code presented in table 1.

Local cultivars exhibited adaptation to specific environments; thus, farmers have selected for yield stability within environmental subsets. 'Zamorano', a Honduran red bean variety released in 1952, is commonly planted during the second growing season. In this environmental subset it ranked seventh in yield, whereas it ranked 24th in the first growing season (table 2).

Disease severity studies showed that Desarrural $(Q)$ was often high yielding in the absence of anthracnose. However, anthracnose has the potential to reduce the yield of Desarrural by more than $50 \%$ (12). 'Cuarenteño' (R), a Honduran landrace widely used in Olancho, had an MSD significantly smaller than the pooled MSD (fig. 2). 'Danli 46' (T), a local cultivar grown in El Paraíso, had the highest overall mean yield and an average stability (table 1; fig. 2). The lack of a wider acceptance of Danli 46 by Honduran farmers has been attributed to later maturity and poor seed type.

Small red bean lines from CIAT (Centro Internacional de Agricultura Tropical) (U-Y) varied substantially in mean yield and yield stability characteristics (fig. 2). Line RAB-205 (v) was recently released in Honduras as 'Catrachita'. Its overall mean yield and deviation mean square were similar to those of most genotypes in the trials. It should be noted, 


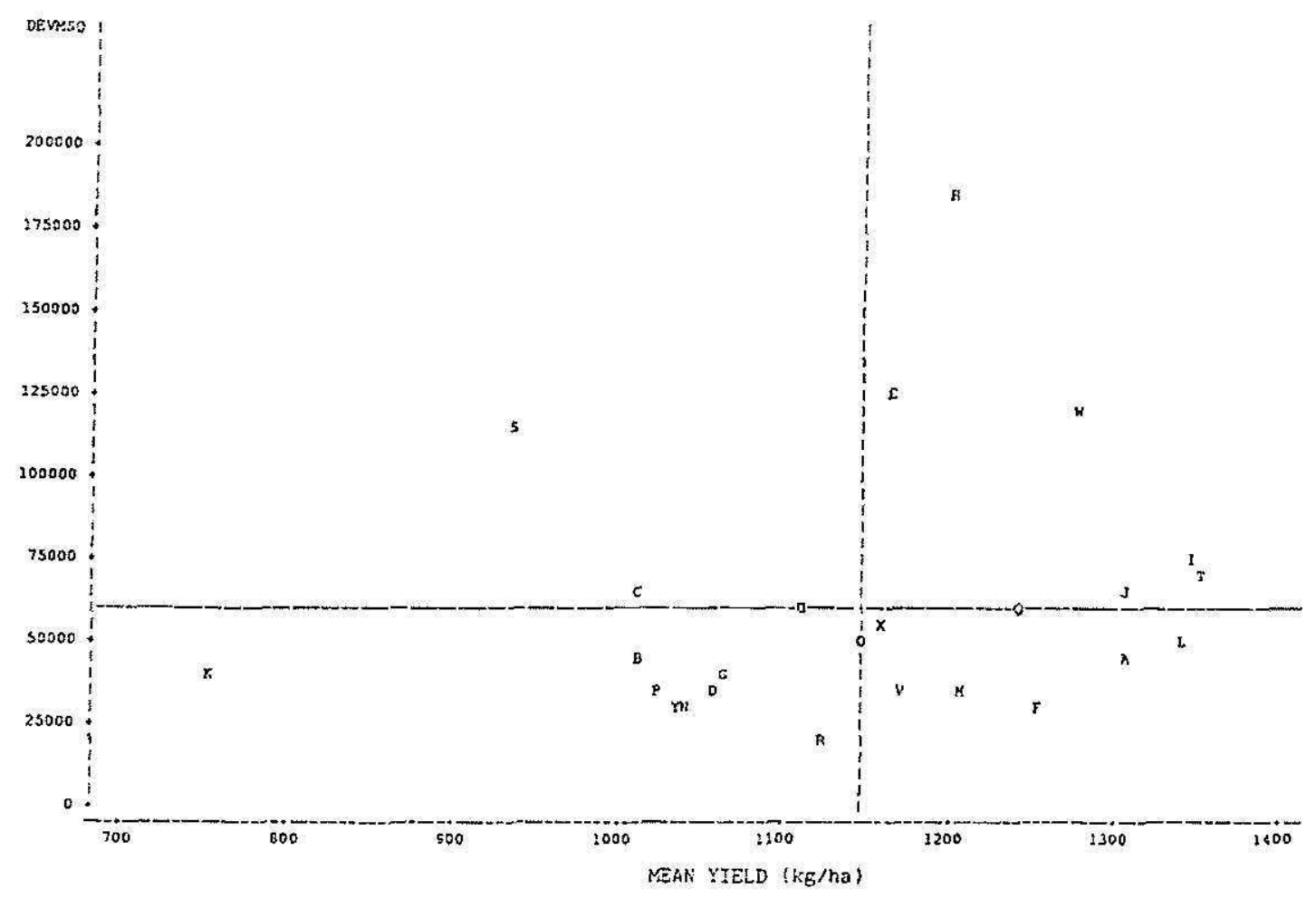

FIG. 2.-Scatter diagram of bean genotype mean yields in $\mathrm{kg} / \mathrm{ha}$ and deviation mean squares from the regression of mean yields of genotypes onto mean environmental yields. Genotypes are represented by letters using the code presented in table I. Vertical line indicates yield mean over all genotypes; horizontal line indicates mean pooled deviation square over all genotypes.

however, that 'Catrachita' has more disease resistance than Honduran varieties.

Black-seeded lines 'B-190 ${ }^{(\mathrm{A})}$,' '3B-5-1 ${ }^{(\mathrm{F})}$,' and ' $8325-7^{(\mathrm{L})}$ ' had both high mean yields and desirable stability characteristics (fig. 2). Results from 2 years of trials conducted in the Dominican Republic (2) also identified B-190 as having high yield potential and stable yield characteristics. These genotypes may be useful as parents in breeding small-red beans for greater yield and improved yield stability.

Cultivar development can select for wide adaptation, or seek to identify genotypes with adaptation to specific regions and seasons. Results from this research indicate that genotypes with wide adaptation or with adaptation to specific regions and seasons can be identified. However, a sophisticated seed production and distribution system may be needed for specific adaptation to be fully exploited.

\section{LITERATURE CITED}

1. Allen, F. L., R. E. Comstock and D. C. Rasmusson, 1978. Optimal environments for yield testing. Crop Sci. 18: 747-51.

2. Beaver, J. S., C. V. Paniagua, D. P. Coyne and G. F. Freytag, 1985. Yield stability of dry bean cultivars in the Dominican Republic. Crop Sci. 25: 923-26. 
3. - and R. R. Johnson, 1981. Yield stability of determinate and indeterminate soybeans adapted to the Northern United States. Crop Sci. 21: 449-54.

4. Becker, H. C., 1981. Correlations among some statistical measures of phenotypic stability. Euphytica 30: 835-40.

5. Casler, M. D. and A. W. Hovin, 1984. Genotype $\times$ environment interaction for reed canarygrass forage yield. Crop Sci. 24: 633-36.

6. Eberhart, S. A. and W. A. Russell, 1966. Stability parameters for comparing varieties. Crop Sci. 6: 36-40.

7. Freeman, G. H., 1973. Statistical methods for the analysis of genotype-environment interactions. Heredity 31 : 339-54.

8. Hildebrand, P. E., 1984. Modified stability analysis of genotype-environment interactions. Heredity 31: 339-54.

9. Kelly, J. D., M. W. Adams and G. V. Varner, 1987. Yield stability of determinate and indeterminate dry bean cultivars. Theor. Appl. Genet. 74: 516-21.

10. Ministerio de Economía, Dirección General de Estadística y Censos, 1984. Encuesta Agricola Nacional. Comayaguela, D. C., Honduras. 102 p.

11. Rosielle, A. A. and J. Hamblin, 1981. Theoretical aspects of selection for yield in stress and non-stress environments. Crop Sci. 21: 943-46.

12. Young, R. A., J. R. Moncada and J. C. Rosas, 1988. Cuantificación de daños por antracnosis (Colletorichum lindemuthianum (Sacc. \& Magn.) Scrib.) en dos cultivares hondureños de frijol. In: Reporte Anual de Investigación (PAI-88), Dep. Agron., Escuela Agrícola Panamericana, El Zamorano, Honduras. 